\title{
Hereditary anaemias in Portugal: epidemiology, public health significance, and control
}

\author{
M C Martins, G Olim, J Melo, H A Magalhães, M O Rodrigues
}

\begin{abstract}
A countrywide prospective study aimed at establishing the prevalence of the haemoglobinopathy genes in the Portuguese population was carried out by screening 15208 randomly selected blood samples from young males. This male based survey provided the opportunity of assessing simultaneously the prevalence of the red cell enzyme glucose-6-phosphate dehydrogenase (G6PD) deficiency, thus giving a picture of these important hereditary anaemias in Portugal.

The results showed a low average frequency of $\beta$ thalassaemia $(0.45 \%)$ and haemoglobin $S(0.32 \%)$ carriers as well as G6PD deficiency $(0.51 \%)$. However, these disorders are unevenly distributed throughout the country with a higher prevalence in some areas, mainly in the south. The relationship of this pattern of haemoglobinopathies to the known haplotypes linked to $\beta$ thalassaemia and sickle cell disease, relevant historical events, and local selective pressure was investigated. $\mathrm{Hb} \mathrm{D}$ and $\mathrm{Hb} \mathrm{J}$ are the commonest other structural variants. The implemented programme for control of these hereditary anaemias is described. ( $\mathcal{F}$ Med Genet 1993;30:235-9)
\end{abstract}

The first cases of Cooley's anaemia in Portugal were reported in $1938^{1}$ and subsequently there have been many other reports of haemoglobin disorders among the Portuguese. ${ }^{2-5}$ More recently the common $\beta$ thalassaemia gene mutations and the known $\beta^{s}$ haplotypes have been described in the Portuguese population. ${ }^{6-10}$

G6PD deficiency is usually also present where $\mathrm{Hb}$ disorders occur. 'Favism' is diagnosed occasionally throughout the country and the significance of the disorder was agreed at a recent meeting held in Albufeira in 1991.

Despite these reports, the true prevalence of haemoglobin disorders and G6PD deficiency in Portugal and their importance for public health remained uncertain. Following a national meeting, a national haemoglobinopathy group was established, and with their help a large scale random study was carried out to answer these questions.

\section{Materials and methods}

Universal conscription for military service is the rule in Portugal. The population sample studied was exclusively formed of young males attending the three military recruitment centres before any kind of selection (medical, physical, or any other kind), thus representing a random sample of the Portuguese population.

Blood samples from 15208 young males attending the three military selection centres in Oporto (north), Coimbra (centre), and Setúbal (south) were collected in tubes with EDTA as anticoagulant and analysed in the Clinical Chemistry and Haematology Laboratory of the Portuguese National Institute of Health. Red blood cell indices and haemoglobin electrophoresis were performed on all samples; 13785 were screened for G6PD deficiency. The subjects' place of origin was noted and the results expressed in relation to administrative districts.

Red cell indices were measured using a Coulter Counter $\left(S_{8}-90\right)$ under strict calibration and internal and external quality control (4 C Coulter Counter cell control, participation in the UK External Quality Assessment Scheme). Hb electrophoresis was carried out on cellulose acetate strips with tris-EDTAboric acid buffer at $\mathrm{pH}=8 \cdot 9$. $\mathrm{Hb} \mathrm{A}_{2}$ quantification was by microcolumn chromatography on samples with microcytosis and hypochromia $(\mathrm{MCH}<28 \mathrm{pg}$ and $\mathrm{MCV}<78 \mathrm{fl}$, which we have previously found to be cut off values of $\mathrm{MCH}$ and $\mathrm{MCV}$ between Portuguese $\beta$ thalassaemia and non- $\beta$ thalassaemia carriers).

Whenever suggested by the electrophoretic pattern, $\mathrm{Hb} \mathrm{F}$ levels were quantified by the alkali denaturation method of Betke et al. ${ }^{11}$ The presence of $\mathrm{Hb} \mathrm{S}$ was confirmed by electrophoresis on agar gel with citrate buffer, $\mathrm{pH}=6 \cdot 1$, a low solubility test in a high molarity phosphate buffer with dithionite, and a positive sickling test. ${ }^{12}$

For G6PD the blood samples were screened by the NADP reduction fluorescent method. ${ }^{13}$ G6PD deficient samples were assayed quantitatively. ${ }^{14}$

\section{Results}

The findings are summarised in the table. Among the 15208 blood samples analysed for $\mathrm{Hb}$ disorders $0.45 \%$ showed $\beta$ thalassaemia trait $(95 \%$ confidence limits $0.45 \pm 0.011)$ and $0.32 \%$ showed sickle cell trait $(95 \%$ confidence limits $0.32 \pm 0.089$ ). The geographical distribution by administrative districts is shown in figs 1 and 2. The prevalence of both increases from the north (total prevalence less than $0.1 \%$ ) towards the south (total prevalence more than $2 \%$ in three districts).

Less common structural variants of haemoglobin were also found, the most frequent being $\mathrm{Hb} \mathrm{D}(n=9)$ and $\mathrm{Hb} \mathrm{J}(n=13)$. Their 
Prevalence of both $\mathrm{Hb}$ disorders and G6PD deficiency by administrative district in Portugal.

\begin{tabular}{|c|c|c|c|c|c|c|c|}
\hline \multirow{3}{*}{$\begin{array}{l}\text { Administrative } \\
\text { districts }\end{array}$} & \multirow{3}{*}{$\begin{array}{l}\text { Population } \\
\text { (1988) } \\
\text { (thousand) }\end{array}$} & \multicolumn{4}{|c|}{$\mathrm{Hb}$ disorders } & & \\
\hline & & \multirow[b]{2}{*}{ No tested } & \multicolumn{3}{|c|}{$\%$ carriers } & \multicolumn{2}{|c|}{ G6PD } \\
\hline & & & $\mathrm{B}^{\text {th }}$ & $\mathrm{B}^{\mathrm{S}}$ & Total & No tested & $\%$ defic \\
\hline Aveiro (C) & $667 \cdot 9$ & 800 & 0.37 & 0.12 & 0.49 & 724 & 0.41 \\
\hline $\operatorname{Beja}(S)$ & $176 \cdot 6$ & 808 & 0.99 & $1 \cdot 11$ & $2 \cdot 10$ & 634 & $0 \cdot 31$ \\
\hline $\operatorname{Braga}(\mathrm{N})$ & $774 \cdot 9$ & 396 & $0 \cdot 25$ & 0.00 & 0.25 & 398 & 0.00 \\
\hline Bragança $(N)$ & $184 \cdot 3$ & 283 & 0.00 & 0.00 & 0.00 & 282 & 0.00 \\
\hline Castelo Branco (C) & $222 \cdot 5$ & 359 & 0.52 & 0.00 & 0.52 & 432 & 1.85 \\
\hline Coimbra (C) & $446 \cdot 5$ & 1149 & $0 \cdot 78$ & $0 \cdot 17$ & 0.95 & 1205 & $0 \cdot 17$ \\
\hline Évora $(S)$ & $173 \cdot 6$ & 669 & 1.57 & 0.71 & $2 \cdot 28$ & 623 & $0 \cdot 16$ \\
\hline Faro $(\mathbf{S})$ & $342 \cdot 1$ & 766 & 1.08 & 0.68 & 1.76 & 767 & 1.04 \\
\hline Guarda (C) & $195 \cdot 1$ & 333 & 0.00 & 0.00 & 0.00 & 301 & 0.00 \\
\hline Leiria (C) & $436 \cdot 0$ & 460 & $1 \cdot 16$ & $0 \cdot 23$ & 1.39 & 428 & 0.93 \\
\hline Lisboa $(\mathrm{C})$ & $2127 \cdot 6$ & 3151 & 0.32 & $0 \cdot 50$ & 0.82 & 2536 & 0.83 \\
\hline Portalegre (S) & $136 \cdot 8$ & 543 & $0 \cdot 18$ & $0 \cdot 18$ & 0.36 & 523 & 0.38 \\
\hline Porto $(\mathrm{N})$ & $1676 \cdot 9$ & 2029 & 0.00 & 0.05 & 0.05 & 2024 & 0.05 \\
\hline Santarem $(C)$ & $460 \cdot 2$ & 422 & 0.94 & 0.71 & 1.65 & 419 & 0.72 \\
\hline Setúbal (S) & $789 \cdot 2$ & 1188 & $1 \cdot 16$ & 0.99 & $2 \cdot 15$ & 874 & 1.37 \\
\hline Viana do Castelo (N) & $266 \cdot 5$ & 641 & 0.00 & 0.00 & 0.00 & 376 & 0.00 \\
\hline Vila Real $(\mathbf{N})$ & $262 \cdot 2$ & 433 & 0.00 & 0.00 & 0.00 & 428 & 0.00 \\
\hline Viseu $(\mathbf{N})$ & $422 \cdot 3$ & 818 & $0 \cdot 24$ & $0 \cdot 00$ & $0 \cdot 24$ & 811 & $0 \cdot 12$ \\
\hline & $9761 \cdot 2$ & 15208 & $0.45^{*}$ & $0.32 *$ & $0.77^{*}$ & 13785 & $0.51^{*}$ \\
\hline
\end{tabular}

$\mathrm{N}$, north, C, central, $\mathrm{S}$, south.

*Poisson distribution.

$95 \%$ confidence limits: $\beta$ thal: $0 \cdot 45 \pm 0 \cdot 011$, Hb S: $0.32 \pm 0 \cdot 089, \beta$ thal $+\mathrm{Hb}$ S: $0 \cdot 77 \pm 0.014$, G6PD def: $0.51 \pm 0 \cdot 109$.

geographical distribution was more or less evenly scattered.

Out of the initial number of blood samples analysed for $\mathrm{Hb}$ disorders, 13785 were screened for G6PD deficiency and 68 were found to be deficient, giving a low overall prevalence of $0.51 \%$ in males $(95 \%$ confidence limits $0 \cdot 51 \pm 0 \cdot 109)$. Fig 3 shows that the distribution of G6PD deficiency resembles that of $\beta$ thalassaemia and sickle cell trait, ranging from zero in several northern regions to $1.37 \%$ in the south, with $1.85 \%$ in one central province.

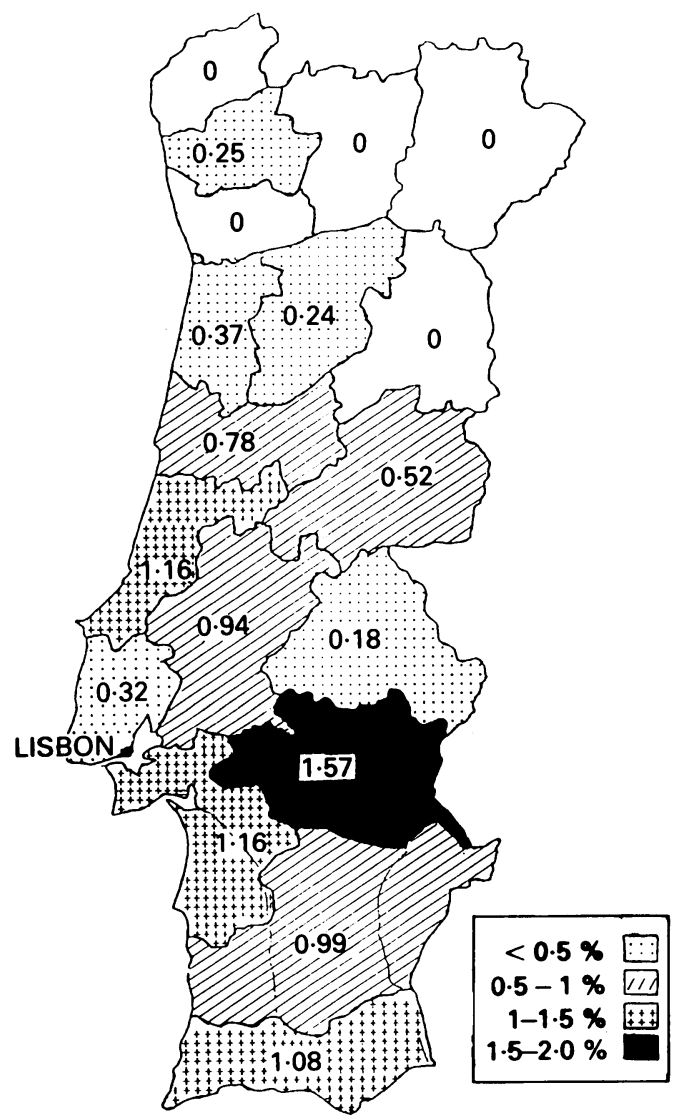

Figure 1 Prevalence of carriers of $\beta$ thalassaemia trait (\%).

\section{Discussion}

EPIDEMIOLOGY

This study established for the first time a picture of the prevalence of hereditary anaemias in the whole of Portugal. The differences between the north and the south may be related to several factors.

Migrants from Mediterranean areas settled predominantly in the south which, unlike the north, is level and offered better conditions for settlement, agriculture, fishing, and mining (fig 4). In fact the four commonest Mediter-

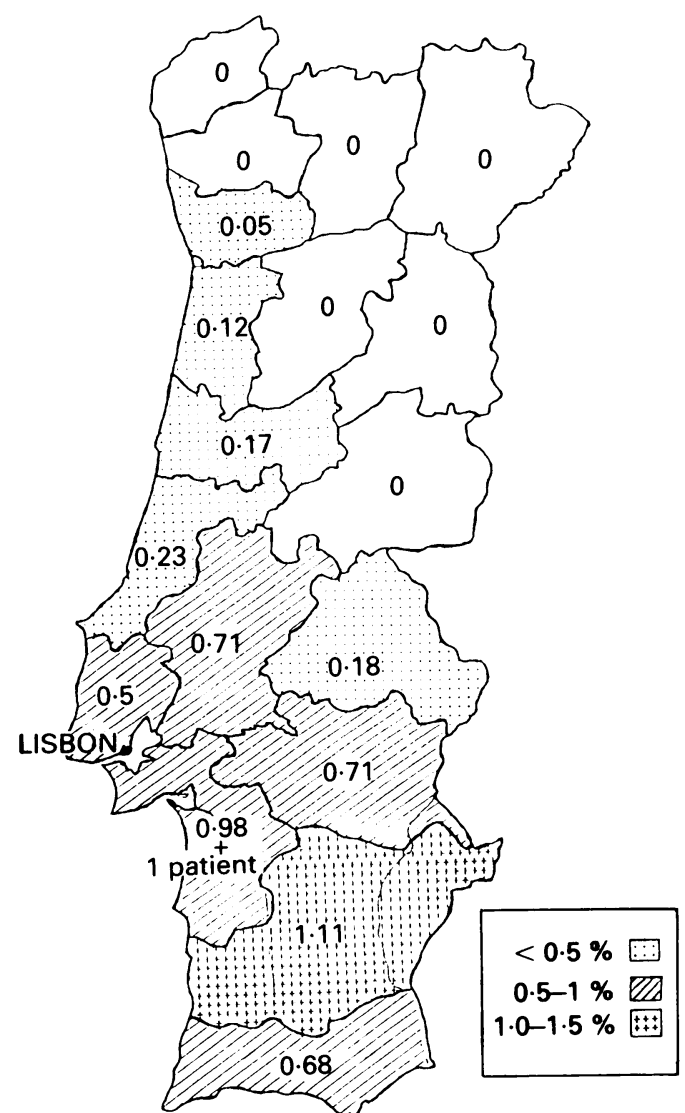

Figure 2 Prevalence of carriers of haemoglobin $S$ trait (\%). 


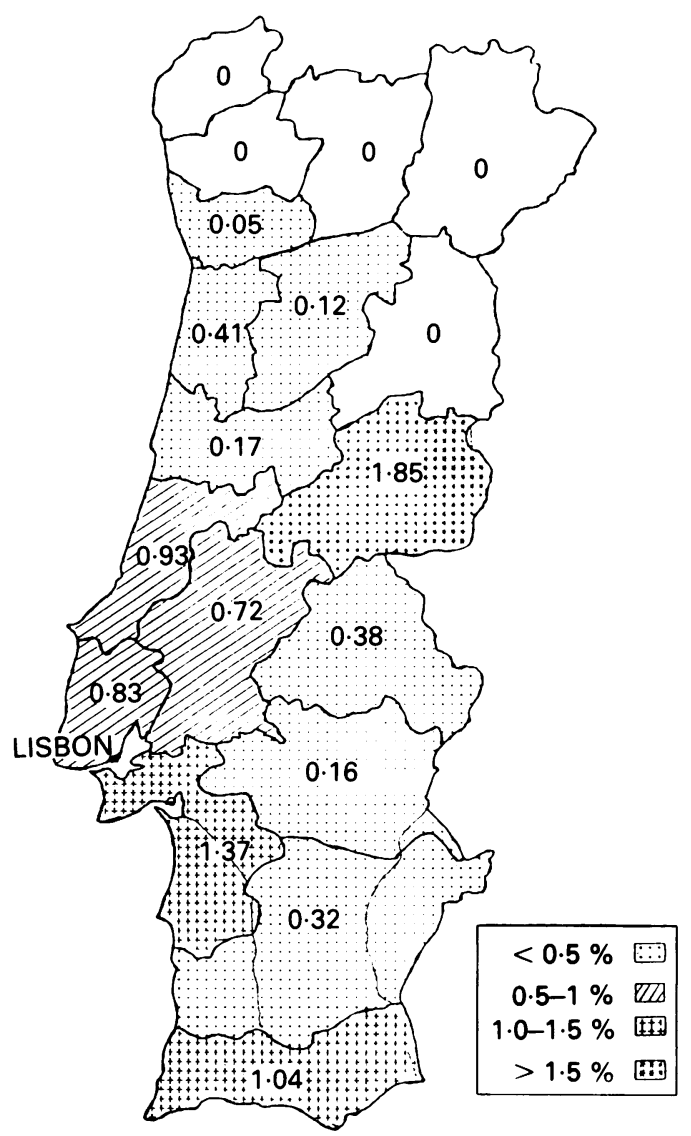

Figure 3 Prevalence of glucose-6-phosphate dehydrogenase deficiency ( $\%)$.

ranean $\beta$ thalassaemia mutations are found in the Portuguese..$^{6-8}$

In the 15th century and later, African slaves were imported to work in the swampy rice fields on the banks of southern rivers: this is the most likely explanation for the present prevalence and distribution of sickle cell trait (fig 4). Recent studies have shown the presence of the three main African sickle cell haplotypes (Bantu, Benin, and Senegalese) among phenotypically Caucasian Portuguese: this corres-
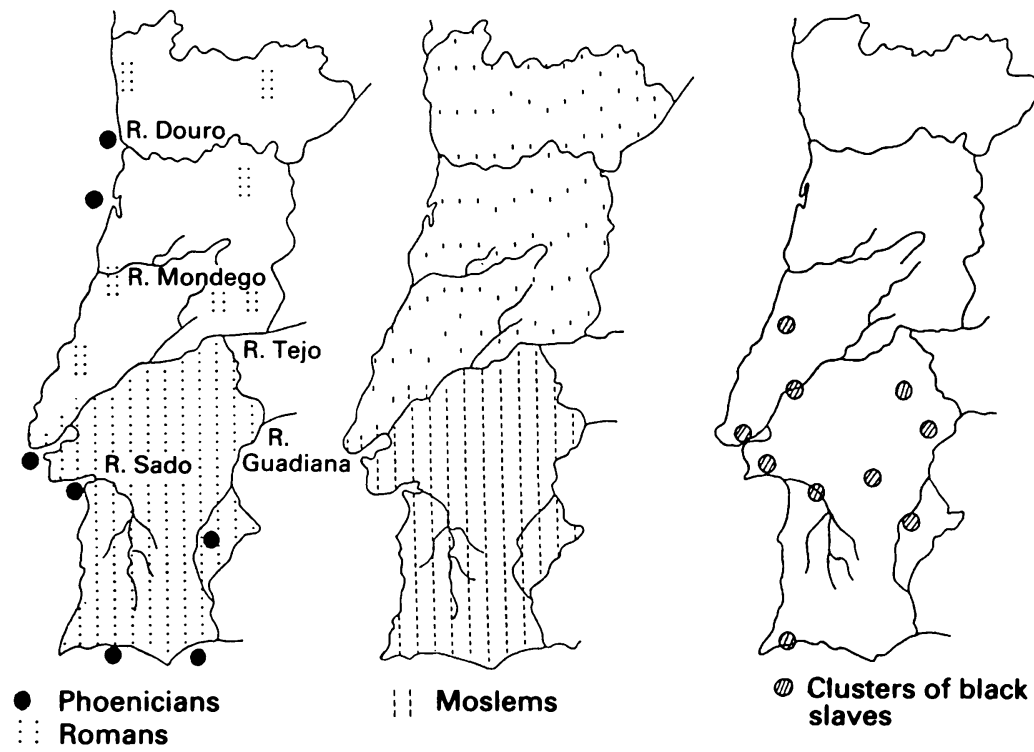

Figure 4 Ancient settlements and clusters of black slaves in what is now Portugal. ponds with the widespread areas of Portuguese settlement in Africa. ${ }^{910}$

Malaria was formerly frequent in the low valleys of the rivers Sado, Guadiana, and Tejo (fig 4). This may have tended to maintain or increase the local frequency of $\beta$ thalassaemia, sickle cell, and G6PD deficiency genes.

Further studies are planned to identify the mutations in the G6PD deficient samples. Information on the proportion of Mediterranean and African mutations will cast further light on the origins of these conditions in Portugal.

This study has provided the scientific basis for a National Haemoglobinopathy Control Programme which is progressively involving the primary health care services in the most affected districts and specialised clinics in the relevant hospitals.

PUBLIC HEALTH IMPORTANCE

The Hardy-Weinberg equation ${ }^{15}$ may be used to calculate the minimum frequency of homozygous births. However, the calculation is inaccurate since it cannot take account of irregularities of distribution. Applied to this survey and using the total figure for $\beta$ thalassaemia $+\beta^{s}$ trait per district (table) the calculation gives a minimum annual birth rate of three homozygotes in Portugal. This figure is inconsistent with the observed number of at least 300 living patients, 218 with sickle cell disease (SS or $S / \beta$ thalassaemia).

This discrepancy is probably the result of two factors. (1) A survey of this type cannot detect 'hot spots' with a high frequency of carriers. Three sickle cell hot spots are known, Coruche and Alcarcer do Sal in the low valleys of the rivers Tejo and Sado respectively, and Pias in the south-east. Others may exist. (2) The survey also omitted the specific gene contribution of immigrants from former Portuguese colonies in Africa, particularly from the Cabo Verde islands, $7 \%$ of whom carry sickle cell trait. In a recently organised national register of sickle cell patients $61.9 \%$ are African in origin.

Even without considering special populations at risk, the survey indicates the existence of between 73795 and 76528 carriers of $\beta$ thalassaemia or AS in Portugal (table). These are significant figures since these genes can interact to produce severe genetic disease and also carry risks in themselves. $\beta$ thalassaemia trait carries an important risk of misdiagnosis as iron deficiency anaemia, followed by inappropriate iron therapy, while sickle cell trait carries some anaesthetic risks and risks associated with endurance exercises (particularly in the armed forces) and must be excluded in pilots. G6PD deficiency also carries risks associated with certain drugs, particularly antimalarials.

\section{PROGRAMME FOR CONTROL OF HEREDITARY} ANAEMIAS

Progressive understanding of these facts is making people aware of the need for a programme for hereditary anaemias in Portugal. A 
programme for the control of both the $\mathrm{Hb}$ disorders and G6PD deficiency, following WHO guidelines, ${ }^{16}$ is now being implemented in seven districts (fig 5 ). In each district there is a group responsible for coordination and an appropriate strategy for prevention (carrier screening, information, and genetic counselling).

This programme is based on the government health centres which serve the whole population, and the national network of district Public Health Laboratories, all of which participate in the National External Quality Assessment Scheme in Haematology.

Blood samples from health centre users in groups with a presumed high gene frequency or who, if positive, require immediate family studies and counselling (pregnant women before 3 months' gestation, young couples, immigrants of African extraction, gypsies) are analysed at the district Public Health Laboratory. The tests used at this level are cheap and simple, including red cell indices and haemoglobin $S$ solubility test. Samples found to be positive are sent to the National Institute of Health in Lisbon for $\mathrm{Hb} \mathrm{A}_{2}$ estimation or

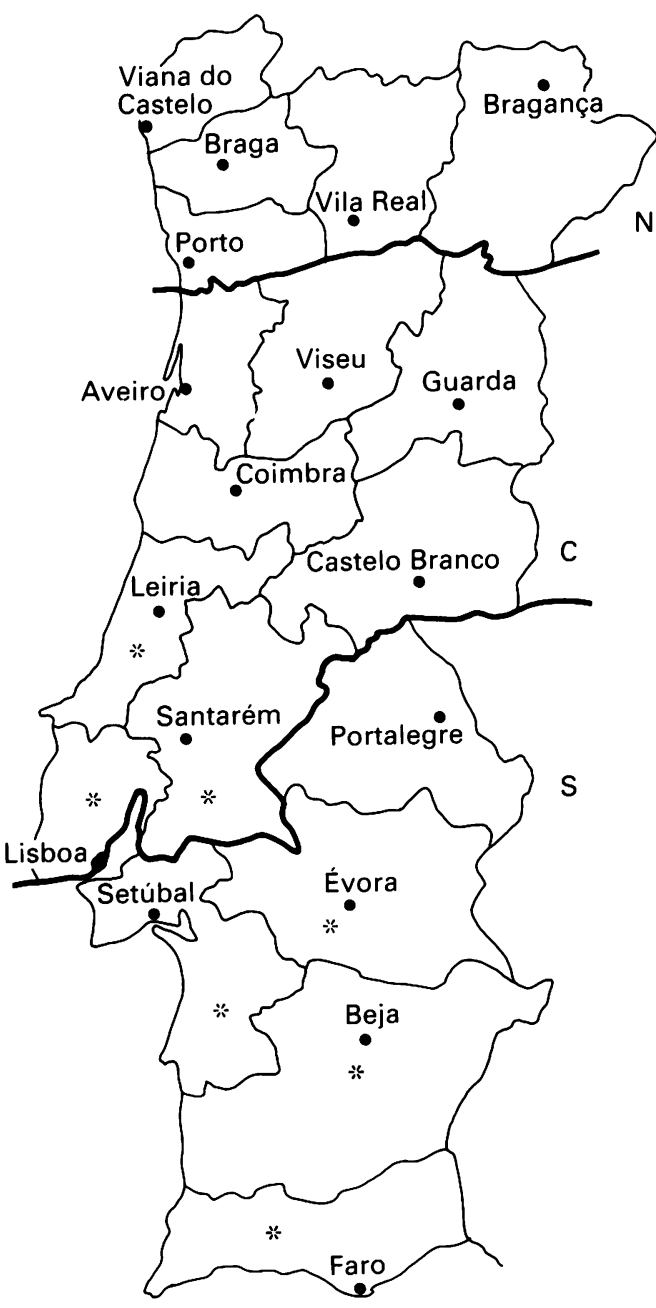

* Districts in which the Control Programme is implemented

Figure 5 Administrative districts in Portugal by region $N$, north, $C$, centre, $S$, south. haemoglobin electrophoresis or both for definitive identification of $\mathrm{Hb} \mathrm{S}$.

Single carriers are counselled using an appropriate information leaflet by a trained member of the health centre team (general practitioner, nurse). A 'carrier card' is issued. This draws attention to the personal risks for the carrier, such as iatrogenic disease with iron overload in $\beta$ thalassaemia trait if mistreated with iron and sickling crisis in AS in severe hypoxia or extreme physical stress.

Every carrier is requested to ask his or her family to come for study. Couples at risk identified in this way are sent to a specialist genetic counsellor available in Lisbon who also periodically visits the three district hospitals in the most affected regions. They may, when indicated, request prenatal diagnosis, performed at the National Institute of Health.

G6PD deficient subjects are given a special leaflet. They are advised not to ingest the foodstuffs and medicines listed in order to avoid a haemolytic crisis.

In every district data are collected to improve knowledge of the epidemiology of hereditary anaemias in Portugal, to find carrier 'hot spots', and to identify couples at risk.

The control programme also includes treatment of patients. Most patients attend central specialist centres in relevant hospitals in Lisbon, Coimbra, and Oporto which follow WHO guidelines, ${ }^{17}$ providing adequate blood, desferrioxamine, and desferrioxamine infusion pumps. In Faro and Beja most patients are treated in the local hospitals and in Beja psychological and social support is also being organised. A parents' association has started at a national level.

We believe that this programme of screening and counselling, based in the primary care system, will provide a structural basis for other genetic programmes, for example, for cystic fibrosis, in the future.

The people involved at the national and district level in the Haemoglobinopathy Control Programme in Portugal are listed below. A $M$ Coelho (coordinator). Haemoglobinopathy group, national level: D Espirito Santo, M J Feijóo, F Graça, J Lavinha, H A Magalhães, M C Martins, G Olim, R Pereira, M J Peres, M O Rodrigues, L Rosado. District level: Beja: A Calado, A Cavaco, A Carvalho, L Carvalho, M Gaspar; Evora: M L Fialho, A Madeira, M C Nascimento; Faro: F Inez, P Santos, M Sequeira; Leiria: M G Sousa, M O Santos; Lisboa: J Brandão; Santarém: H Mendes, L Portugal, J Rodrigues; Setúbal: $M$ C Almeida, E Esteves.

The authors thank Dr B Modell for advice as WHO consultant and for her kind review of this paper, the Portuguese Armed Forces for allowing the blood collections, Drs M M Freitas (Instituto Nacional de Saúde, Porto), $\mathrm{M} \mathrm{H}$ Bento (Lab ARS Coimbra), M C Almeida, (Lab ARS Setúbal), and I Picanço and L Batalha for technical help.

1 Cordeiro Ferreira M. Dois casos clínicos de anemia de Cooley. Lisboa Med 1938;15:24-54.

2 Ribeiro do Rośario M, Colaço FM. Nosografia da hemoglo- 
bina S em Portugal continental. Gaseta Med Portuguesa, 1985;XI:541-53.

3 Trincão C. Emoglobine anomali loro distribuzione nei territori portoghesi. Med Clin Sperimentale 1961;VI:5.

4 Trincão C, Martins de Melo J, Lorkin PA, Lehmann H. Hemoglobin J Paris in the south of Portugal (Algarve). Acta Haematol (Basel) 1968;39:291-8.

5 Melo J. Comentários acerca de la difusion de la hemoglobina $S$ em Portugal y probablemente en la Península. Sangre 1966;11:388-94.

6 Tamagnini GP Lopes MC, Castanheira ME, Wainscoat JS, Wood WG. B $^{+}$thalassaemia - Portuguese type: clinical, haematological and molecular studies of a newly defined form of $\beta$ thalassaemia. $\mathrm{Br} \mathcal{f}$ Haematol 1983;54:189-200

7 Coutinho Gomes MP, Costa MGG, Braga LD, et al. $\beta$ thalassaemia in the Portuguese population. Hum Genet 1988;78:13-15.

8 Faustino P, Osório Almeida L, Espirito Santo D, et al. Genetic, clinical and geographic heterogeneity of $\beta$ thalassaemia in the Portuguese population. Hum Genet 1992;89:573-6.

9 Monteiro C, Rueff J, Falcão AB, Portugal LS, Weatherall DJ, Kulozic AE. The frequency an DJ, Kulozic AE. The frequency and origin of the sickle cell mutation in the district of Coruche/Portugal. Hum
10 Lavinha J, Gonçalves J, Faustino P, et al. Importation route of sickle cell trait into Portugal: contribution of molecular epidemiology. Hum Biol 1992;64:891-901.

11 Betke K, Marti HR, Schlicht I. Estimation of small percentages of foetal haemoglobin. Nature 1959;184:1877-8.

12 Laboratory methods for detecting hemoglobinopathies. USA: Centers for Disease Control, 1984

13 Beutler E. Glucose-6-phosphate dehydrogenase (G6PD) and 6-phosphogluconate dehydrogenase (G6PD). In: Red cell metabolism. 3rd ed New York: Grune \& Stratton, cell metabolism

14 Standardization of procedures for the study of glucose-6phosphate dehydrogenase: report of WHO scientific group. WHO Technical Report No 366. Geneva: WHO, 1967.

15 Emery AEH. Hardy-Weinberg equilibrium and the estimation of gene frequencies. In: Methodology in medical genetics. Edinburgh: Churchill-Livingstone, 1976:3-9.

16 World Health Organization. Community control of hereditary anaemias. Memorandum from a WHO meeting. Bull WHO 1983;61:63-80.

17 World Health Organization. Hereditary anaemias: genetic basis, clinical features, diagnosis and treatment. Bull WHO 1982;60:643-60. 